Praca poglądowa/Review

\title{
Aktualne miejsce nilotynibu i dazatynibu w leczeniu przewlekłej białaczki szpikowej
}

\section{Nilotinib and dasatinib - current place in the therapy of chronic myeloid leukemia}

\section{Tomasz Sacha *, Joanna Wącław}

Katedra Hematologii Collegium Medicum Uniwersytetu Jagiellońskiego, kierownik: prof. dr hab. med. Aleksander B. Skotnicki, Kraków, Polska

I N F O R M A C J E O A R T Y U L E

Historia artykułu:

Otrzymano: 08.06.2015

Zaakceptowano: 07.07.2015

Dostępne online: 17.07.2015

\section{Słowa kluczowe:}

- inhibitory kinaz tyrozynowych

2 generacji

- przewlekła białaczka szpikowa

- leczenie

Keywords:

- Second-generation tyrosine kinase inhibitors

- Chronic myeloid leukemia

- Treatment

\begin{abstract}
A B S T R A C T
Tyrosine kinase inhibitors (TKI) have revolutionized the practise of treatment of chronic myeloid leukemia. The emergence of resistance to imatinib - first TKI - has led to the development of second-generation TKI's (2GTKI). Nilotinib and dasatinib are 2GTKI's routinely used in the tretament of CML patients intolerant or resistant to imatinib since couple of years. The approval of nilotinib and dasatinib in newly diagnosed chronicphase CML patients was granted based on the results of studies comparing 2GTKI's with imatinib used in the first-line setting. More patients treated up-front with nilotinib or dasatinib reach early molecular response, and deep molecular response (DMR), which is achieved quicker than under imatinib therapy. The achievement of EMR increases the chance for major molecular response and may prolong progression-free and overall survival. DMR is one of the key eligibility criteria to TKI - discontinuation trials. Considering the current goal of CML therapy, reducing the time of exposure to adverse drug reactions and health economic aspects, the early achievement of DMR with the use of 2GTKI and subsequently discontinuation of therapy seems to be a reasonable and safe treatment strategy for substantial proportion of patients.
\end{abstract}

(C) 2015 Polskie Towarzystwo Hematologów i Transfuzjologów, Instytut Hematologii i Transfuzjologii. Published by Elsevier Sp. z o.o. All rights reserved.

\section{Wstęp}

Przewlekła białaczka szpikowa (PBSz) jest klonalną chorobą mieloproliferacyjną charakteryzującą się występowaniem chromosomu Filadelfia $(\mathrm{Ph})$ powstającego w rezultacie wzajemnej wymiany fragmentów ramion długich chromosomu 9 i 22 pary [t(9;22)(q34;q11)] [1, 2]. Powyższa translokacja wiedzie do powstania onkogenu fuzyjnego BCR/ABL1, a w konsekwencji białka bcr/abl1 o stałej, konstytutywnej i nadmiernej aktywności kinazy tyrozynowej. Odkrycie, że gen

\footnotetext{
* Adres do korespondencji: Katedra Hematologii Collegium Medicum Uniwersytetu Jagiellońskiego ul. Kopernika 17, 31-501 Kraków, Polska. Tel.: +48 1242476 00; fax: +48 124247426.

Adres email: sachatom@gmail.com (T. Sacha).

http://dx.doi.org/10.1016/j.achaem.2015.07.001

0001-5814/@ 2015 Polskie Towarzystwo Hematologów i Transfuzjologów, Instytut Hematologii i Transfuzjologii. Published by Elsevier Sp. $\mathrm{z}$ o.o. All rights reserved.
} 
$B C R / A B L 1$ ma kluczowe znaczenie w powstawaniu i rozwoju PBSz [3], doprowadziło do opracowania inhibitorów kinaz tyrozynowych (IKT). Pierwszy z nich (imatynib) krótko po jego wprowadzeniu do leczenia stał się lekiem pierwszego wyboru w terapii PBSz [4]. Pojawiające się przypadki oporności na imatynib zainicjowały badania nad inhibitorami kinaz tyrozynowych 2. generacji (IKT2G) obdarzonymi większą siłą blokowania kinazy bcr/abl1 i wykazującymi potencjał przełamywania części mechanizmów oporności związanych, między innymi, z występowaniem mutacji domeny kinazy bcr/abl1 [5]. IKT2G okazały się skuteczne w leczeniu chorych z opornością lub nietolerancją imatynibu, a wyniki badań nad ich skutecznością w pierwszym rzucie leczenia PBSz doprowadziły do ich zarejestrowania także w tym wskazaniu. Zgodnie z rekomendacjami European Leukemia Net (ELN), National Comprehensive Cancer Network (NCCN) oraz Stowarzyszenia Polskiej Grupy ds. Leczenia Białaczek (PALG), w leczeniu pierwszego rzutu PBSz można stosować imatynib, nilotynib lub dazatynib [6-8]. Artykuł omawia miejsce nilotynibu i dazatynibu w leczeniu PBSz w kontekście korzyści $\mathrm{z}$ ich stosowania i ewentualnych zagrożeń.

\section{Inhibitory kinaz tyrozynowych drugiej generacji w drugiej linii leczenia PBSz}

Skuteczność IKT2G w leczeniu chorych z opornością lub nietolerancją imatynibu wykazano w wielu badaniach klinicznych [9-12]. Po 48-miesięcznym okresie obserwacji w badaniu oceniającym skuteczność nilotynibu w dawce $2 \times 400 \mathrm{mg} / \mathrm{d}$ 59\% pacjentów osiągnęło większą odpowiedź cytogenetyczną (MCyR; Major Cytogenetic Response), a $45 \%$ całkowitą odpowiedź cytogenetyczną (CCyR; Complete Cytogenetic Response). Całkowite przeżycie (OS; Overall Survival) i przeżycie wolne od progresji (PFS; Progression-free Survival) wyniosły odpowiednio $78 \%$ i $57 \%$ [11]. W badaniu TIDELII oceniano skuteczność zwiększenia dawki imatynibu do $800 \mathrm{mg} / \mathrm{d}$ (grupa 1) w porównaniu ze zmianą leczenia na nilotynib (grupa 2) w przypadku oporności na imatynib w inicjalnej dawce $600 \mathrm{mg} / \mathrm{d}$. Przyjętymi punktami końcowymi było osiągnięcie redukcji liczby transkryptu genu BCR/ ABL1 do $\leq 10 \%, \leq 1 \%$ oraz $\leq 0,1 \%$ po odpowiednio 3,6 i 12 miesiącach leczenia. Po 24-miesięcznym okresie obserwacji jedynie $11 \%$ pacjentów z grupy 1 kontynuowało leczenie dawką imatynibu $800 \mathrm{mg} / \mathrm{d}$ i uzyskało MMR, a zmiana leku na nilotynib umożliwiła uzyskanie MMR przez kolejnych $15 \%$ chorych. Łączny odsetek MMR uzyskanych w badaniu wyniósł 73\%. 3-letnie OS i PFS wyniosły odpowiednio $96 \%$ i 95\%. Autorzy konkludują, że wczesna zmiana leczenia na nilotynib (dokonana u 30\% wszystkich badanych) na podstawie wyników badania poziomu genu BCR/ABL1 jest bardziej skuteczna niż zwiększenie dawki imatynibu do $800 \mathrm{mg} / \mathrm{d}$, jednocześnie podkreślają, że powyższa strategia leczenia chorych ze świeżo rozpoznaną PBSz pozwala na rozpoczęcie leczenia imatynibem i wczesną identyfikację chorych wymagających bardziej intensywnego leczenia [13]. W badaniu START-R porównywano skuteczność dazatynibu w dawce $70 \mathrm{mg} 2 \times$ d i imatynibu w dawce $800 \mathrm{mg} / \mathrm{d}$ u 150 chorych na PBSz opornych na standardową dawkę imatynibu $(400 \mathrm{mg} / \mathrm{d})$. Po 2-letnim okresie obserwacji chorzy w grupie dazatynibu osiągnęli większe odsetki całkowitej odpowiedzi hematologicznej (CHR; Complete Hematologic Response), MCyR ( $53 \%$ us $33 \%$; $p=0.017$ ), CCyR ( $44 \%$ us $18 \%$; $p=0,0025$ ) oraz MMR ( $29 \%$ vs $12 \%$; $p=0,028)$ w porównaniu z grupą leczoną imatynibem [14]. Dotychczas nie przeprowadzono randomizowanych badań bezpośrednio porównujących efektywność IKT2G w leczeniu drugiego rzutu, dlatego aktualne rekomendacje ELN oraz PALG nie wskazują, który z dostępnych IKT2G należy zastosować w leczeniu 2. linii $[6,8]$. W przypadku chorych opornych na imatynib wybór leku drugiego rzutu powinien nastąpić po ocenie mutacji domeny kinazowej genu BCR/ABL1, ponieważ w przypadku jej obecności poszczególne leki mogą różnić się skutecznością [15, 16]. Kolejnymi czynnikami wpływającymi na wybór leku są profil działań ubocznych i bezpieczeństwa, analiza chorób współistniejących i stosowanego $\mathrm{z}$ ich powodu leczenia oraz omówienie $\mathrm{z}$ chorym jego możliwości dostosowania się do zaleceń lekarskich dotyczących przyjmowania danego preparatu IKT2G.

\section{Inhibitory kinaz tyrozynowych drugiej generacji w pierwszej linii leczenia PBSz}

Wyniki 5-letniej obserwacji w badaniu DASISION (Dasatinib versus Imatinib Study in Treatment-Naive CML Patients), $\mathrm{w}$ przebiegu którego $\mathrm{u}$ chorych $\mathrm{w}$ pierwszej linii leczenia zastosowano po randomizacji imatynib w dawce $400 \mathrm{mg} / \mathrm{d}$ lub dazatynib w dawce $100 \mathrm{mg} / \mathrm{d}$ wskazują, że CCyR po 12 miesiącach leczenia uzyskało $77 \%$ pacjentów w grupie dazatynibu oraz 66\% w grupie imatynibu ( $p=0,007)$. Również skumulowany odsetek uzyskanej MMR, głębokiej odpowiedzi molekularnej $\mathrm{MR}^{4,5}\left(\mathrm{MR}^{4,5}\right.$ - odpowiedź molekularna z 4,5-krotną redukcją liczby transkryptu genu BCR/ABL1 w skali logarytmicznej) oraz wczesnej odpowiedzi molekularnej (EMR; Early Molecular Response; redukcja liczby transkryptu genu BCR/ABL1 do $\leq 10 \%$ po 3 miesiącach leczenia) był istotnie większy $\mathrm{u}$ chorych leczonych dazatynibem w porównaniu $\mathrm{z}$ imatynibem (Tab. I). Ponadto dazatynib lepiej niż imatynib zapobiegał progresji (jej odsetek wyniósł odpowiednio 4,6\% i 7,3\%). Nie zaobserwowano jednak istotnych statystycznie różnic w 5-letnim OS oraz PFS u chorych leczonych dazatynibem

Tabela I - Wybrane rezultaty badania DASISION po 5-letnim okresie obserwacji [17]

Table I - Selected results of the DASISION study after 5-year follow-up [17]

\begin{tabular}{lcc}
$\begin{array}{l}\text { Po 5-letnim okresie } \\
\text { obserwacji }\end{array}$ & $\begin{array}{c}\text { Dazatynib } \\
100 \mathrm{mg} / \mathrm{d}\end{array}$ & $\begin{array}{c}\text { Imatynib } \\
400 \mathrm{mg} / \mathrm{d}\end{array}$ \\
\hline $\begin{array}{c}\text { Skumulowany } \\
\text { odsetek CCyR ( } \mathrm{p} \text { vs IM) }\end{array}$ & $83 \%(\mathrm{p}=0,187)$ & $78 \%$ \\
$\begin{array}{c}\text { Skumulowany } \\
\text { odsetek MMR ( } \mathrm{p} \text { vs IM) }\end{array}$ & $76 \%(\mathrm{p}=0,002)$ & $64 \%$ \\
$\begin{array}{c}\text { Skumulowany } \\
\text { odsetek MR }\end{array}$ & $42 \%(\mathrm{p}=0,025)$ & $33 \%$ \\
Osiągnięcie EMR & $84 \%$ & $64 \%$ \\
\hline IM - imatynib & & \\
\hline
\end{tabular}


Tabela II - Wybrane rezultaty badania ENESTnd po 5-letnim okresie obserwacji [19]

Table II - Selected results of the ENESTnd study after 5-year follow-up [19]

\begin{tabular}{|c|c|c|c|}
\hline & $\begin{array}{l}\text { Nilotynib } \\
300 \mathrm{mg} 2 \times \mathrm{d}\end{array}$ & $\begin{array}{l}\text { Nilotynib } \\
400 \mathrm{mg} 2 \times \mathrm{d}\end{array}$ & $\begin{array}{l}\text { Imatynib } \\
400 \mathrm{mg} / \mathrm{d}\end{array}$ \\
\hline \multicolumn{4}{|c|}{ Po 5-letnim okresie obserwacji } \\
\hline MMR, \% (p vs IM) & $77(<0,0001)$ & $77(<0,0001)$ & 60 \\
\hline $\mathrm{MR}^{4,5}, \%$ (p us IM) & $54(<0,0001)$ & $52(<0,0001)$ & 31 \\
\hline \multicolumn{4}{|c|}{ Osiągnięcie EMR wg grup ryzyka Sokala } \\
\hline Niski & $93 \%$ & $95 \%$ & $79 \%$ \\
\hline Pośredni & $92 \%$ & $89 \%$ & $70 \%$ \\
\hline Wysoki & $86 \%$ & $82 \%$ & 44 \\
\hline \multicolumn{4}{|c|}{ Osiągnięcie $\mathrm{MR}^{4,5}$ wg grup ryzyka Sokala } \\
\hline Niski & $53 \%$ & $62 \%$ & $37 \%$ \\
\hline Pośredni & $60 \%$ & $50 \%$ & $33 \%$ \\
\hline Wysoki & $45 \%$ & $42 \%$ & $23 \%$ \\
\hline
\end{tabular}

w porównaniu z imatynibem (OS i PFS odpowiednio 91\% i 85\% oraz 90\% i 86\%) [17]. Podobne wyniki uzyskano w badaniu SPIRIT2. Po 12 miesiącach leczenia MMR uzyskało istotnie więcej chorych leczonych dazatynibem niż imatynibem (58,1\% us $42,6 \%, p<0,001)$, jednak po okresie obserwacji trwającej średnio 34 miesiące nie stwierdzono istotnych różnic w zakresie OS i PFS chorych leczonych dazatynibem lub imatynibem [18]. Po minimum 5-letnim okresie obserwacji $\mathrm{w}$ badaniu ENESTnd (Evaluating Nilotinib Efficacy and Safety in Clinical Trials of Newly Diagnosed Ph+ CML patients), w którym po randomizacji chorzy byli leczeni nilotynibem w dawce $2 \times 300 \mathrm{mg} / \mathrm{d}$ bądź $2 \times 400 \mathrm{mg} / \mathrm{d}$ lub imatynibem w dawce $400 \mathrm{mg} / \mathrm{d}$ stwierdzono istotnie większy skumulowany odsetek MMR, MR ${ }^{4,5}$ i EMR (Tab. II) Czas konieczny do uzyskania MR $^{4,5}$ był istotnie statystycznie krótszy w grupie leczonej nilotynibem. (Tab. II). Nilotynib lepiej niż imatynib zapobiegał progresji PBSz do fazy akceleracji lub kryzy blastycznej. Jej odsetek wynosił odpowiednio 3,9\% i 2,1\% dla nilotynibu w dawce $2 \times 300 \mathrm{mg} / \mathrm{d}$ lub $2 \times 400 \mathrm{mg} / \mathrm{d}$ oraz $7,4 \%$ u chorych leczonych imatynibem. Ponadto w grupach leczonych nilotynibem odnotowano mniej zgonów. [19].

\section{Inhibitory kinaz tyrozynowych drugiej generacji - profil działań niepożądanych}

Uwzględnienie toksyczności leku powinno być jednym z kluczowych czynników branych pod uwagę przy podejmowaniu decyzji o jego ewentualnym zastosowaniu. Do najczęstszych działań niepożądanych nilotynibu (występują u $\geq 10 \%$ pacjentów) należą: nudności, wysypka, bóle głowy, zmęczenie, świąd skóry, łysienie, bóle mięśni i bóle brzucha. Dolegliwości te mają najczęściej nasilenie niewielkie do umiarkowanego i zwykle nie wymagają trwałego zmniejszenia dawki bądź odstawienia leku. Toksyczność hematologiczna występuje w postaci małopłytkowości (18\%), neutropenii (15\%) i anemii (8\%). Ponadto nilotynib może wywoływać hepatotoksyczność objawiającą się laboratoryjnie wzrostem stężeń bilirubiny, ALT, AST i ALP. Zwykle ma ona jednak charakter przejściowy i rzadko wiąże się $\mathrm{z}$ trwałym uszkodzeniem wątroby. Rzadkim, ale potencjalnie niebezpiecznym działaniem niepożądanym nilotynibu oraz dazatynibu jest możliwość wydłużenia odstępu QT. Może ono skutkować groźnymi komorowymi zaburzeniami rytmu, zwłaszcza częstoskurczem typu torsade de pointes [20]. Dlatego niezbędne jest wykonanie EKG przed włączeniem leczenia nilotynibem lub dazatynibem oraz okresowo w jego trakcie. Od kilku lat przedmiotem intensywnych badań jest wpływ nilotynibu na metabolizm glukozy. W badaniach ENIGMA1 i 2 wykazano wystąpienie istotnej hiperglikemii, hiperinsulinemii oraz wzrost insulinooporności, a także hipercholesterolemię już po 3 miesiącach leczenia nilotynibem [21, 22]. Zarówno rekomendacje ELN, jak i PALG nie zalecają stosowania nilotynibu u chorych $\mathrm{z}$ niekontrolowaną cukrzycą [6, 8]. W codziennej praktyce należy brać pod uwagę dane mówiące o tym, że kryteria wyrównania cukrzycy spełnione są u niewielkiego tylko odsetka chorych [23]. Nilotynib może zwiększać ryzyko incydentów sercowo-naczyniowych. Chorzy leczeni nilotynibem w pierwszej linii są nawet 10-krotnie bardziej narażeni na ryzyko rozwoju choroby okluzyjnej tętnic obwodowych (PAOD; Peripheral Arterial Occlusive Disease) niż chorzy leczeni imatynibem [24]. U chorych z PBSz i wcześniej rozpoznaną PAOD nilotynib nie jest zalecany. Po 6-letnim okresie obserwacji w badaniu ENESTnd objawy choroby wieńcowej wystąpiły u 3,2\% chorych leczonych nilotynibem w dawce $300 \mathrm{mg} 2 \times /$ dobę, u $4 \%$ chorych leczonych nilotynibem w dawce $400 \mathrm{mg} 2 \times /$ dobę i u $1,1 \%$ chorych leczonych imatynibem. PAOD rozwinęła się tylko u chorych leczonych nilotynibem (u 4,3\% pacjentów otrzymujących dawkę $300 \mathrm{mg} 2 \times$ /dobę i u 3,2\% pacjentów leczonych dawką $400 \mathrm{mg} 2 \times$ /dobę). [19]. Do najczęstszych działań niepożądanych dazatynibu (występujących u $\geq 10 \%$ pacjentów) należą: mielosupresja, retencja płynów (najczęściej w postaci wysięku do opłucnej), biegunka, bóle głowy, bóle mięśniowo-szkieletowe, wysypka i nudności. Toksyczność hematologiczna w stopniu 3.-4. w leczeniu pierwszej linii najczęściej objawia się neutropenią (24\%), następnie małopłytkowością (19\%) i niedokrwistością (12\%) [25]. Po 5-letnim okresie obserwacji w badaniu DASISION wysięki opłucnowe pojawiły się u $28 \%$ pacjentów, z czego w $26 \%$ przypadków miały niewielkie nasilenie (stopień 1 . lub 2. wg CTCAE). $62 \%$ pacjentów, u których wystąpiło to powikłanie, wymagało czasowego odstawienia leku (średnio na $14 \mathrm{dni}$ ). Nie przeszkodziło to jednak w osiągnięciu CCyR u 96\%, MMR u $82 \%$, a $\mathrm{MR}^{4,5}$ u $50 \%$ chorych [17]. Pojawienie się wysięku opłucnowego jest czynnikiem predykcyjnym wystąpienia tętniczego nadciśnienia płucnego (PAH; Pulmonary Arterial Hypertension) - groźnego, choć rzadkiego powikłania leczenia dazytynibem [26]. Ze względu na ryzyko wystąpienia tego powikłania u chorych, u których planowane jest rozpoczęcie leczenia dazatynibem, zalecane jest przeprowadzenie badania przedmiotowego ze szczególnym uwzględnieniem oceny pod kątem chorób sercowo-płucnych. W razie obecności objawów klinicznych lub u chorych z ryzykiem chorób serca bądź płuc wskazane jest wykonanie badania echokardiograficznego. W wypadku wykrycia PAH nie zaleca się stosowania dazatynibu. Terapia dazatynibem może powodować niewydolność serca (2-4\% pacjentów), dlatego lek nie jest zalecany u chorych z tym rozpoznaniem [27]. Dazatynib nie wpływa natomiast niekorzystnie na metabolizm glukozy 
oraz lipidów ani nie zwiększa ryzyka niedokrwiennych incydentów sercowo-naczyniowych [17].

\section{Znaczenie uzyskania wczesnej odpowiedzi na leczenie}

W dążeniu do poprawy wyników leczenia PBSz poszukiwane są nowe parametry mogące prognozować dalszy przebieg choroby i wcześnie identyfikować grupę chorych obciążonych większym ryzykiem niepowodzenia terapii lub progresji choroby, u których korzyść może przynieść modyfikacja leczenia. Stopień redukcji liczby transkryptu genu BCR/ABL1 po 3. i 6. miesiącu leczenia IKT stał się nowym czynnikiem prognostycznym. Redukcja do $\leq 10 \%$ po 3 miesiącach leczenia imatynibem wiąże się nie tylko $z$ większą szansą uzyskania MMR, mniejszym skumulowanym odsetkiem niepowodzenia terapii, ale także $\mathrm{z}$ większą szansą na uzyskanie długotrwałego (8-letniego) przeżycia wolnego od zdarzeń niepożądanych (EFS; Event-Free Survival), PFS i OS [28, 29]. Podobne wyniki uzyskano w przebiegu dwóch dużych badań klinicznych porównujących skuteczność IKT2G i imatynibu stosowanych $\mathrm{w}$ pierwszym rzucie leczenia PBSz [30, 31]. Potwierdzono w nich zależność pomiędzy odsetkami uzyskiwanych 5-letnich przeżyć: całkowitego, wolnego od progresji i wolnego od transformacji do fazy akceleracji lub kryzy blastycznej (TFS; Transformation Free Survival) a osiągnięciem redukcji liczby transkryptu genu $B C R / A B L 1$ do $\leq 10 \%$ po pierwszych 3 miesiącach leczenia. W badaniu DASISION odsetki PFS, OS i TFS u chorych leczonych dazatynibem z liczbą transkryptu $\leq 10 \%$ lub $>10 \%$ po 3 miesiącach leczenia wynosiły odpowiednio $93 \%$ i $68 \%$, $96 \%$ i $86 \%$ oraz $87 \%$ i $83 \%$. Analogicznie, u chorych z liczbą transkryptu $\leq 10 \%$ lub $>10 \%$ po 3 miesiącach leczenia odsetek progresji do fazy akceleracji lub kryzy blastycznej po 5 latach obserwacji wynosił dla dazatynibu odpowiednio 3\% i 14\%, a dla imatynibu 3\% i 15\%. W badaniu ENESTnd odsetki PFS i OS dla imatynibu w zależności od uzyskanej redukcji poziomu transkrytpu genu BCR/ABL1 po 3 miesiącach do $\leq 10 \%$ lub $>10 \%$ wynosiły odpowiednio $98 \%$ i $83 \%$ oraz $99 \%$ i $86 \%$, a dla nilotynibu 95\% i 83\% oraz 97\% i 87\%. Różnice w odsetkach pomiędzy badanymi grupami osiągały znamienność statystyczną i występowały niezależnie od przyjmowanego IKT. Jednak znaczną redukcję liczby kopii transkryptu po pierwszych 3 miesiącach terapii w każdym z tych badań znamiennie częściej uzyskiwali chorzy otrzymujący IKT2G. W badaniu DASISION redukcję $\leq 10 \%$ uzyskało $64 \%$ pacjentów otrzymujących imatynib i 84\% leczonych dazatynibem, w badaniu ENESTnd taką redukcję odnotowano u 66\% leczonych imatynibem i 90\% przyjmujących nilotynib (różnice istotne statystycznie) [17, 19]. W przebiegu innego badania potwierdzono, że wczesne osiągnięcie CCyR podczas leczenia IKT wiąże się $\mathrm{z}$ większymi odsetkami 3-letniego EFS i OS, jednak osiągnięcie MMR kiedykolwiek w trakcie terapii nie wydłużało EFS ani OS u chorych, którzy uzyskali CCyR [32-35]. Zmniejszenie poziomu transkryptu genu BCR/ABL1 do $\leq 1 \%$ w 3 . miesiącu leczenia IKT identyfikuje grupę chorych o najkorzystniejszym rokowaniu. Są to pacjenci z największymi szansami na osiągnięcie bardzo głębokiej odpowiedzi molekularnej (przynajmniej $\mathrm{MR}^{4.5}$ ) w przebiegu dalszego leczenia. Po 5 latach badania ENESTnd wśród chorych, którzy po pierwszych 3 miesiącach leczenia uzyskali redukcję poziomu transkryptu genu BCR/ABL1 do $\leq 1 \%$, odsetek pacjentów, którzy osiągnęli $\mathrm{MR}^{4.5}$, wyniósł $70 \%$ (chorzy otrzymujący nilotynib) i 67\% (chorzy leczeni imatynibem) [19]. Odsetek chorych osiągających po pierwszych 3 miesiącach leczenia redukcję poziomu transkryptu do $\leq 1 \%$ jest znamiennie większy wśród pacjentów otrzymujących IKT2G [17, 19]. Osiągnięcie głębokiej odpowiedzi molekularnej jest jednym z głównych kryteriów kwalifikujących do badań klinicznych nad możliwością odstawienia leczenia.

\section{Znaczenie uzyskania głębokiej odpowiedzi molekularnej - możliwość odstawienia leczenia}

Wiele obserwacji klinicznych sugeruje, że u części chorych możliwe jest bezpieczne odstawienie leczenia IKT i uzyskanie długotrwałego przeżycia wolnego od konieczności ponownego jego wdrożenia (TFR; Treatment-free Remission). Wyniki badania STIM (STop IMatinib) wskazują, że możliwe jest utrzymanie całkowitej remisji molekularnej (CMR; Complete Molecular Response) u 39\% chorych, u których odstawiono imatynib po uzyskaniu CMR trwającej przynajmniej przez 2 lata. Czynnikami ryzyka nawrotu molekularnego w analizie wielowariantowej były: płeć żeńska, krótszy niż 5 lat okres leczenia imatynibem i wysoki wskaźnik Sokala w chwili rozpoznania. Do nawrotu molekularnego poza jednym przypadkiem doszło w okresie do 7 miesięcy od odstawienia imatynibu, a ponowne wdrożenie leczenia przywróciło utraconą odpowiedź u wszystkich pacjentów [36]. Celem badania EURO-SKI (Europe Stop Kinase Inhibitors) jest określenie przeżycia wolnego od nawrotu molekularnego definiowanego jako potwierdzona utrata MMR po odstawieniu TKI 1. lub 2. generacji u chorych pozostających przez minimum rok w odpowiedzi molekularnej $\mathrm{MR}^{4}$ lub głębszej uzyskanej rezultacie przynajmniej 3letniego leczenia IKT. Po 2 latach obserwacji prowadzonej u 200 chorych przeżycie wolne od nawrotu molekularnego w 6. miesiącu po odstawieniu leczenia (czas, w którym nawraca ok. u 90\% pacjentów) wynosi 61\% [37]. Podobny odsetek przeżycia wolnego od konieczności ponownego wdrożenia IKT z chwilą utraty MMR uzyskano w badaniu STIM2 (Stop IMatinib2) wyniósł on 61\% po roku obserwacji [38]. Wyniki te potwierdzono w innych badaniach, w których odsetek rocznego TFR po odstawieniu imatynibu wahał się w granicach $47-65 \%[39,40]$. Podobne rezultaty uzyskiwane są $\mathrm{w}$ badaniach, w których podejmowane są próby odstawienia IKT2G. W badaniu STOP-2GIKT 12- i 24-miesięczne prawdopodobieństwo TFR bez utraty MMR wynosi odpowiednio 61,4\% i 57\% [41]. W prospektywnym badaniu DADI (DADI; DAsatinib Discontinuation) prawdopodobieństwo 6 miesięcznego TFR $\mathrm{u}$ chorych z CMR uzyskaną w toku leczenia dazatynibem, u których odpowiedź utrzymywała się nieprzerwanie przez przynajmniej rok, wynosi 48,3\% [42]. Powyższe wyniki sugerują, że możliwe jest uzyskanie trwałej TFR u znacznej części chorych, którzy uzyskali bardzo głęboką i długotrwałą odpowiedź molekularną w przebiegu leczenia IKT. Wyniki odstawienia imatynibu i IKT2G są porównywalne, a sam sposób postępowania jest bezpieczny. U żadnego pacjenta nie był on przyczyną progresji choroby, a ponowne wdrożenie 
leczenia u pacjentów z nawrotem molekularnym przywracało utraconą odpowiedź u prawie wszystkich pacjentów.

\section{Podsumowanie}

Imatinib, nilotynib i dazatinib są bardzo skuteczne w uzyskiwaniu odpowiedzi hematologicznej, cytogenetycznej i molekularnej u chorych z noworozpoznaną PBSz. Pacjenci leczeni w pierwszym rzucie nilotynibem lub dazatynibem szybciej i w większym odsetku niż chorzy otrzymujący imatynib uzyskują głębokie odpowiedzi na leczenie. Znaczenie tego faktu dla oceny odległych wyników leczenia PBSz nie jest wprawdzie do końca określone, jednak wyniki badań klinicznych wskazują, że wczesne osiągnięcie odpowiedzi terapeutycznej może wydłużyć przeżycie wolne od progresji, zdarzeń niepożądanych i przeżycie całkowite. Trwała i głęboka odpowiedź molekularna $\left(\mathrm{MR}^{4}\right.$ lub $\left.\mathrm{MR}^{4,5}\right)$ stanowi jedno $\mathrm{z}$ kluczowych kryteriów kwalifikujących do badań nad możliwością odstawienia leczenia, z którego największą korzyść mogą odnieść młodzi pacjenci osiągający głęboką odpowiedź molekularną i odczuwający działania niepożądane IKT. Wprawdzie odsetek pacjentów, u których działania niepożądane imatynibu, nilotynibu lub dazatynibu osiągają 3. lub 4. stopień nasilenia wg CTCAE, jest bardzo niewielki, to jednak, ponieważ występują przewlekle w niewielkim nasileniu, powodują istotne i długotrwałe obniżenie jakości życia $u$ wielu chorych. $W$ badaniu ankietowym obejmującym 448 chorych największe obniżenie jakości życia w porównaniu z dobraną odpowiednio zdrową populacją odnotowano u osób młodych - w wieku pomiędzy 18 a 39 lat, zwłaszcza u kobiet. U chorych natomiast w wieku 60 lat i powyżej raportowana jakość życia była porównywalna ze zdrową populacją w tej samej kategorii wiekowej [43]. Dazatynib i nilotynib mają swoją niepodważalną pozycję jako leki 2. rzutu w leczeniu chorych na PBSz z opornością lub nietolerancją imatynibu. Wobec braku badań porównujących bezpośrednio skuteczność terapii pierwszej linii imatynibem, nilotynibem i dazatynibem każdy z nich może być dobrą opcją leczenia pierwszego rzutu. Wybór leku poza ograniczeniami narzucanymi w Polsce zapisami Programu Lekowego może zależeć od doświadczenia lekarza prowadzącego, określenia celu terapii, wieku pacjenta i jego chorób współistniejących oraz możliwości tolerowania i stosowania się do zaleceń w ramach prowadzonego leczenia. Zważywszy jednak na aktualny cel leczenia PBSz, którym nie jest już tylko przedłużenie przeżycia, lecz możliwość odstawienia terapii i wyleczenie, skrócenie czasu narażenia na działania niepożądane leku, możliwość dokonywania wczesnej modyfikacji terapii w oparciu o wyniki badań molekularnych i wreszcie narastającą liczbę chorych i związany z tym aspekt ekonomiczny, wydaje się, że dla stosunkowo dużej grupy pacjentów próba szybkiego osiągnięcia głębokiej odpowiedzi molekularnej za pomocą zastosowanych jak najwcześniej IKT2G, z następczą fazą eliminacji minimalnej choroby resztkowej oraz odstawieniem leczenia jest możliwą i bezpieczną strategią leczenia PBSz.

\section{Wkład autorów/Authors' contributions}

Według kolejności.

\section{Konflikt interesu/Conflict of interest}

Nie występuje.

\section{Finansowanie/Financial support}

Nie występuje.

\section{Etyka/Ethics}

Treści przedstawione $\mathrm{w}$ artykule są zgodne $\mathrm{z}$ zasadami Deklaracji Helsińskiej, dyrektywami EU oraz ujednoliconymi wymaganiami dla czasopism biomedycznych.

\section{PIŚ M I E N N I C T W O/REFERENCES}

[1] Nowell PC, Hungerford DA. A minute chromosome in human chronic granulocytic leukemia. Science 1960;132:1497-1500.

[2] Rowley JD. A new consistent chromosomal abnormality in chronic myelogenous leukaemia identified by quinacrine fluorescence and Giemsa staining. Nature 1973;243:290-293.

[3] Melo JV, Barnes DJ. Chronic Myeloid Leukaemia as a Model of Disease Evolution in Human Cancer. Nat Rev Cancer 2007;7(6):441-453.

[4] Druker BJ, Lydon NB. Lessons learned from the development of an abl tyrosine kinase inhibitor for chronic myelogenous leukemia. J Clin Invest 2000;105(1):3-7.

[5] O'Brien SG, Guilhot F, Larson RA, et al. Imatinib compared with interferon and low dose cytarabine for newly diagnosed chronic-phase chronic myeloid leukemia. N Engl J Med 2003;348:994-1004.

[6] Baccarani M, Deininger MW, Rosti G, et al. European LeukemiaNet recommendations for the management of chronic myeloid leukemia: 2013. Blood 2013;122:872-884

[7] NCCN Clinical Practice Guidelines in Oncology. Chronic Myelogenous Leukemia. Version I. 2015. NCCN.org.

[8] Sacha T, Lewandowski K, Hellmann A, et al. Rekomendacje PALG dotyczące diagnostyki i leczenia przewlekłej białaczki szpikowej w 2013 r. Acta Hematol Pol 2013;44:345-362.

[9] Hochhaus A, Baccarani M, Deininger M, et al. Dasatinib induces durable cytogenetic responses in patients with chronic myelogenous leukemia in chronic phase with resistance or intolerance to imatinib. Leukemia 2008; 22(6):1200-1206.

[10] Hochhaus A, Kantarjian HM, Baccarani M, et al. Dasatinib induces notable hematologic and cytogenetic responses in chronic-phase chronic myeloid leukemia after failure of imatinib therapy. Blood 2007;109(6):2303-2309.

[11] Giles FJ, le Coutre PD, Pinilla-Ibarz J, et al. Nilotinib in imatinib-resistant or imatinib-intolerant patients with chronic myeloid leukemia in chronic phase: 48-month follow-up results of a phase II study. Leukemia 2013;27: 107-112.

[12] Saglio G, Hochhaus A, Hughes TP, et al. ENESTnd Update: Nilotinib vs Imatinib in Patients With Newly Diagnosed CML-CP and the Impact of Early Molecular Response and Sokal Risk at Diagnosis on Long-Term Outcomes. Blood 2013. Abstract. 92.

[13] Yeung DT, Osborn MP, White DL, et al. TIDEL-II: first-line use of imatinib in CML with early switch to nilotinib for 
failure to achieve time-dependent molecular targets. Blood 2015;125(6):915-923.

[14] Kantarjian H, Pasquini R, Levy V, et al. Dasatinib or highdose imatinib for chronic-phase chronic myeloid leukemia resistant to imatinib at a dose of 400 to 600 milligrams daily: two-year follow-up of a randomized phase 2 study (START-R). Cancer 2009;115(18):4136-4147.

[15] Hughes T, Saglio G, Branford S, et al. Impact of baseline BCR-ABL mutations on response to nilotinib in patients with chronic myeloid leukemia in chronic phase. J Clin Oncol 2009;27:4204-4210.

[16] Muller MC, Cortes JE, Kim DW, et al. Dasatinib treatment of chronic-phase chronic myeloid leukemia: analysis of responses according to preexisting BCR-ABL mutations. Blood 2009;114:4944-4953.

[17] Cortes J, Saglio G, Baccarani M, et al. Final Study Results of the Phase 3 Dasatinib Versus Imatinib in Newly Diagnosed Chronic Myeloid Leukemia in Chronic Phase (CML-CP) Trial (DASISION CA180-056). Blood 2014. Abstract 152.

[18] O'Brien SG, Hedgley C, Adams S, et al. Spirit 2: An NCRI Randomised Study Comparing Dasatinib with Imatinib in Patients with Newly Diagnosed CML. Blood 2014. Abstract 517.

[19] Larson RA, Kim D-W, Issaragrilsil S, et al. Efficacy and Safety of Nilotinib (NIL) vs Imatinib (IM) in Patients (pts) With Newly Diagnosed Chronic Myeloid Leukemia in Chronic Phase (CML-CP): Long-Term Follow-Up (f/u) of ENESTnd. Blood 2014. Abstract 4541.

[20] Tasigna (nilotinib) [prescribing information]. East Hanover, NJ: Novartis Pharmaceuticals Corporation; 2015.

[21] Racil Z, Razga F, Drapalova J, et al. Mechanism of impaired glucose metabolism during nilotinib therapy in patients with chronic myelogenous leukemia. Haematologica 2013;98(10):124-126.

[22] Racil Z, Belohlavkova P, Cetkovsky P, et al. Comparison of Glucose and Lipid Metabolism Abnormality during Nilotinib, Imatinib and Dasatinib Therapy - Results of Enigma 2 Study. Blood 2014. Abstract 1813.

[23] Jankowski M, Bała MM, Płaczkiewicz-Jankowska E, et al. Specialty outpatient care of diabetic patients in Poland - are we far from treatment targets? Rational, design and preliminary results of the OPTIMO study. Pol Arch Med WEWN 2011;121(11):375-383.

[24] Kim TD, Rea D, Schwarz M, et al. Peripheral artery occlusive disease in chronic phase chronic myeloid leukemia patients treated with nilotinib or imatinib. Leukemia 2013;27:1316-1321.

[25] Sprycel (dasatinib) [prescribing information]. Princeton, NJ: Bristol-Myers Squibb Company; 2014.

[26] Montani D, Bergot E, Gunther S, et al. Pulmonary arterial hypertension in patients treated by dasatinib. Circulation 2012;125:2128-2137.

[27] Yeh ET, Bickford CL. Cardiovascular complications of cancer therapy: incidence, pathogenesis, diagnosis, and management. J Am Coll Cardiol 2009;53:2231-2247.

[28] Marin D, Ibrahim AR, Lucas C, et al. Assessment of BCRABL1 transcript levels at 3 months is the only requirement for predicting outcome for patients with chronic myeloid leukemia treated with tyrosine kinase inhibitors. J Clin Oncol 2012;30:232-238.

[29] Hanfstein B, Mueller M, Erben P, et al. Molecular Response After 3 Months of 1st Line Imatinib Therapy Is Predictive for Treatment Failure and Disease Progression In Patients with Chronic Phase Chronic Myeloid Leukemia - a Follow-up Analysis of the German CML Study IV. Blood 2010. Abstract 360.
[30] Marin D, Hedgley C, Clark RE, et al. Predictive value of early molecular response in patients with chronic myeloid leukemia treated with first-line dasatinib. Blood 2012;120:291-294.

[31] Hughes TP, Saglio G, Kantarjian HM, et al. Early molecular response predicts outcomes in patients with chronic myeloid leukemia in chronic phase treated with frontline nilotinib or imatinib. Blood 2014;123(9): 1353-1360.

[32] Jabbour E, Kantarjian HM, Saglio P, et al. Early response with dasatinib or imatinib in chronic myeloid leukemia: 3year follow-up from a randomized phase 3 trial (DASISION). Blood 2014;123(4):494-500.

[33] Saglio B, Hochhaus A, Hughes TP, et al. ENESTnd Update: Nilotinib vs Imatinib in Patients With Newly Diagnosed CML-CP and the Impact of Early Molecular Response and Sokal Risk at Diagnosis on Long-Term Outcomes. Blood (ASH Annual Meeting Abstracts) 2013;632:92.

[34] Jabbour E, Kantarjian H, O'Brien S, et al. The achievement of an early complete cytogenetic response is a major determinant for outcome in patients with early chronic phase chronic myeloid leukemia treated with tyrosine kinase inhibitors. Blood 2011;118:4541-4546.

[35] Jabbour E, Kantarjian HM, O'Brien S, et al. Front-line therapy with second generation tyrosine kinase inhibitors in patients with early chronic phase chronic myeloid leukemia: what is the optimal response? J Clin Oncol 2011;29:4260-4265.

[36] Mahon FX, Rea D, Guilhot J, et al. Discontinuation of imatinib in patients with chronic myeloid leukaemia who have maintained complete molecular remission for at least 2 years: the prospective, multicentre stop imatinib (STIM) trial. Lancet Oncol 2010;11:1029-1035.

[37] Mahon FX, Richter J, Guilhot J, et al. Interim Analysis of a Pan European Stop Tyrosine Kinase Inhibitor Trial in Chronic Myeloid Leukemia: The EURO-SKI study. Blood (ASH Annual Meeting Abstracts) 2014;124:151.

[38] Mahon FX, Nicolini FE, Noël MP, et al. Preliminary Report Of The STIM2 Study: A Multicenter Stop Imatinib Trial For Chronic Phase Chronic Myeloid Leukemia De Novo Patients On Imatinib. Blood 2013. Abstract 654.

[39] Ross DM, Branford S, Seymour JF, et al. Safety and efficacy of imatinib cessation for CML patients with stable undetectable minimal residual disease: results from the TWISTER study. Blood 2013 Jul 25;122(4):515-522.

[40] Oh YLS, Choi S, et al. Discontinuation of BCR-ABL1 tyrosine kinase inhibitor in CML patients with undetectable molecular residual disease for at least 1 year: including updated data from KIDS study. 18th Congress of the European Hematology Association (Meeting Abstracts) 2013;4401.

[41] Aoki J, Ohashi K, Kobayashi T, et al. Sustained complete molecular response of chronic myeloid leukemia after discontinuation of second-generation tyrosine kinase inhibitors. Leuk Lymphoma 2012;53: 1412-1414.

[42] Kimura S, Imagawa J, Okada M, et al. Discontinuation of dasatinib in patients with CML who have maintained complete molecular response for at least one year: results from a prospective discontinuation (dadi) trial. Hematologica 2014;abst:3468.

[43] Efficace F, Baccarani M, Breccia M, et al. Health-related quality of life in chronic myeloid leukemia patients receiving long-term therapy with imatinib compared with the general population. Blood 2011;118:4554-5456. 